複合サイクルを用いたロケットエンジンの高比推力化に関する研究

\title{
Study of Improving LRE's Isp with Use of Combined Cycle
}

\section{1. 粕言}

世界の第一段 LH2/LOX ロケットエンジンの性能比較を Fig.1に示す.一般的に, 燃焼室圧力が低いとコストパフォ ーマンスに優れ, 比推力が高いとミッション達成能力が高 い傾向がある(1). アメリカ合衆国の基幹ロケットであるデ ルタIVロケットシリーズには, 第一段エンジンとして RS-68 エンジンが使用されている。このエンジンは徹底し た低コスト設計が行われ，低圧燃焼ながら推力は大きい。 しかしながら，ガスジェネレータサイクルを採用している ため, 他の LH2/LOX エンジンに比べ比推力が小さい.

本研究では, この RS-68をリファレンスエンジンとして, 他のエンジンサイクルと組み合わせることで比推力の向上 を狙い, より高度なミッション要求に対応できる低コスト で信頼性の高いエンジンの提案と評価を目的とする.

研究の流れは，まず RS-68 の性能計算を行い，計算手法 の妥当性を確認する. 次に提案するサイクルの計算を行い, 燃焼室圧力が比推力に及ぼす影響について既存のサイクル と比較する. 最後に実際に打ち上げたときの比推力変化を 計算し, 平均比推力がどの程度向上したかを考察する.

\section{2. ロケットエンジンサイクル}

\section{1 ガスジェネレータ(G.G)サイクル}

Fig.2.1 に示すように, ガス発生器に推進剤の一部をブリ 一ドし，発生させた燃焼ガスによってタービンを駆動させ るサイクルである．タービン駆動ガスを排出してしまうた め, 閉サイクルと比較して比推力が小さい.

2.2 ガスジェネレータ(G.G)+エキスパンダ(EX)サイクル 比推力向上のためには, タービン排気ガスの流量を減少 させればよい.そこで Fig.2.2に示すように，ガスジェネレ 一タで発生させた燃焼ガスで LH2 タービンを駆動し, 燃焼 器を泠却して得た高温の酸素ガスで LOX タービンを駆動 するサイクルを考案した．また，このサイクルを採用する ことで, LH2 タービンを水素リッチの燃焼ガス, LOX ター ビンを酸素ガスで駆動できるので，ターボポンプのシール が簡素にでき, 信頼性のより高いエンジンが期待できる.

\section{3. 数值計算}

\section{1 固定パラメータ}

各サイクル計算において, 燃焼室流量, 燃焼室混合比, GG 混合比，各ポンプ入口圧力， GG タービン出口圧力を 固定する.またこれらの数值は RS-68 のデータを用いる.

\subsection{G.G サイクル計算}

各ポンプ必要馬力, LH2 タービン流量, LOX タービン流 量を反復計算で求める. RS-68 の性能計算では, 実際の) ズル膨張比を用い, サイクル比較のための計算では, 剥離 限界膨張比ノズルを用いて推力・比推力を計算する.

\section{3 G.G + EXサイクル計算}

まず各ポンプの必要馬力を計算する. 次に LH2 タービン はタービン流量, LOX タービンは圧力比を反復計算で求め, 剥離限界膨張比ノズルを用いて推力・比推力を計算する.な お燃焼室からの受熱量は RL10A3-3(EXサイクル)エンジン の緒元を元に, RS-68での受熱量を仮定する.

Fig.3に計算の流れを示す.
正 平田 邦夫（静岡大学大学院）

rsity, Johoku3-5-1, Hamamatsu, Japan

, Rel

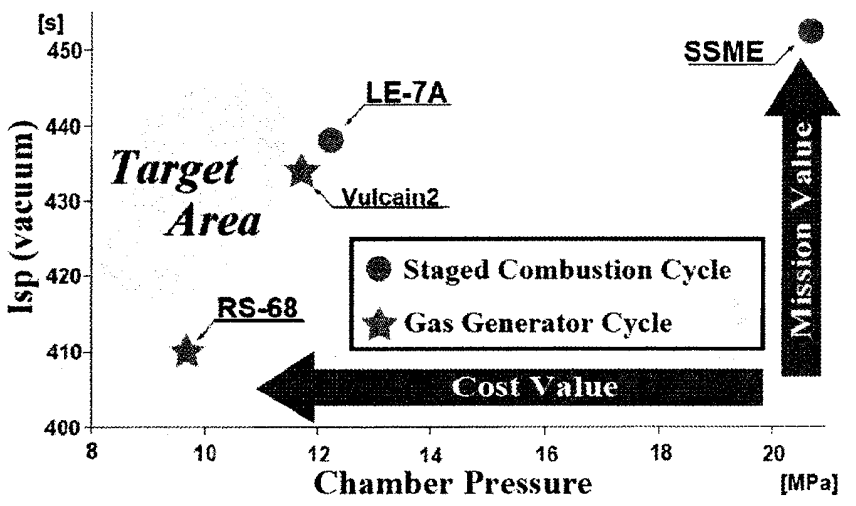

Fig.1 LH2/LOX rocket engine performance comparison
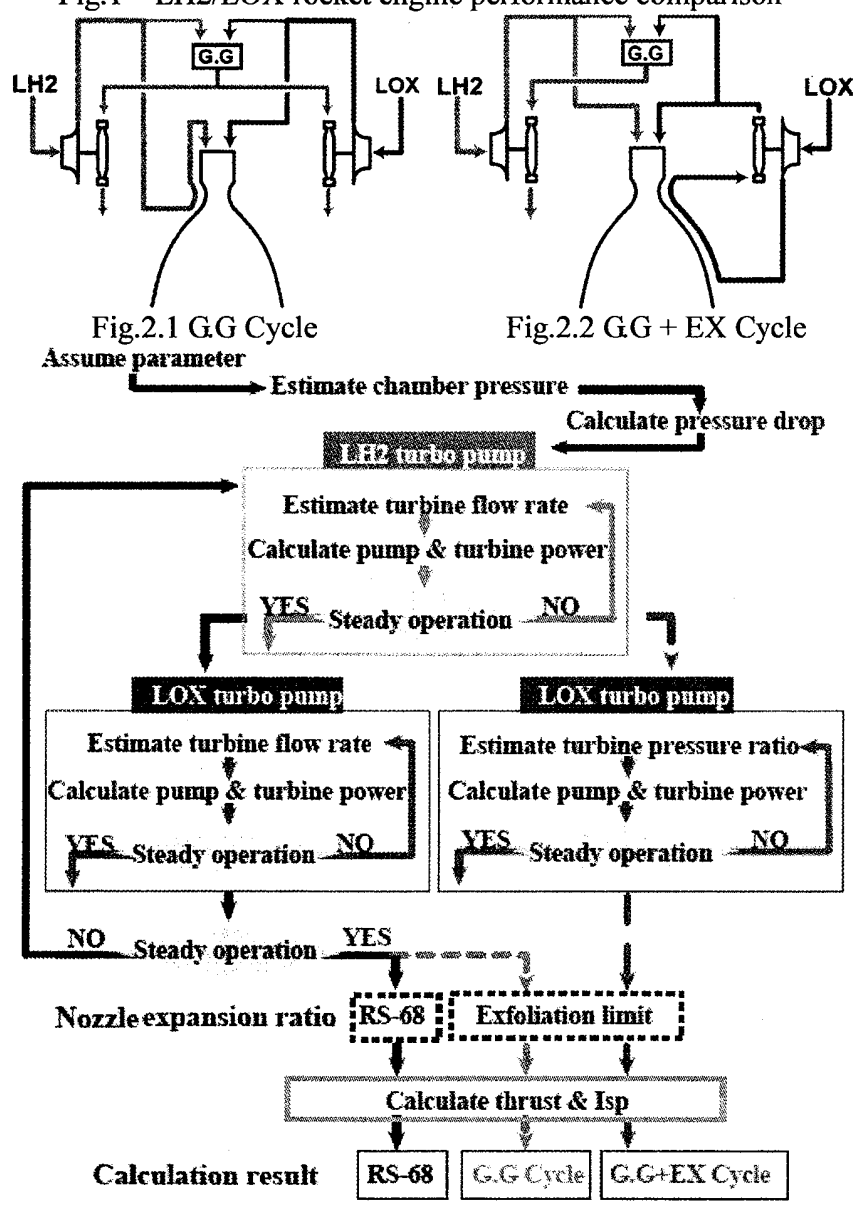

Fig.3 Calculation Flow

\section{4. 基礎式}

記号

\begin{tabular}{|c|c|c|}
\hline Ep;ホホンプ馬力 & $\triangle P$;圧力損失 & $\rho$; 燃料密度 \\
\hline$E t$; タービン馬力 & $k$; 圧力損失係数 & $\gamma$; 比熱比 \\
\hline$\eta_{p}$; ポンプ効率 & $P c$; 燃焼室圧力 & $P a$; 外気圧 \\
\hline$\eta_{t}$; タービン効率 & $g_{0}$; 重力加速度 & $C p$;定圧比熱 \\
\hline$M R c$; 燃焼室混合比 & $\dot{m}_{t}$; タービン流量 & $\dot{m}_{p} ;$ ポンプ流量 \\
\hline$\dot{m}_{C}$; 燃焼室燃料流量 & $\dot{m}_{g} ; \mathrm{GG}$ 燃 & $C_{F}$;推力係数 \\
\hline$C^{*}$; 特性排気速度 & 圧力 & Ps; 剥 \\
\hline
\end{tabular}


$A t$; スロート面積 $A e$; ノズル出口面積 $\quad F$; 推力 $P p i$; ポンプ入口圧力 $P p e$; ポンプ出口圧力 $I s p$; 比推力 $P t i$;タービン入口圧力 Pte;タービン出口圧力 $M s$; 剥離限界マッハ数 $T_{t} ;$ タービン入口温度

\section{1 圧力損失}

各圧力損失は燃焼室圧力に比例するものとする.

$$
\triangle P=k \cdot P c
$$

4.2 ポンプ馬カ・タービン馬カ

ポンプ馬力とタービン馬力の式を次に示す.

$$
\begin{aligned}
& E p=\frac{\dot{m}_{p}}{\eta_{P}} \frac{(P p e-P p i)}{\rho} \\
& E t=\eta_{t} \cdot \dot{m}_{t} \cdot C p \cdot T_{t}\left(1-\left(\frac{P t e}{P t i}\right)^{\frac{\gamma-1}{\gamma}}\right)
\end{aligned}
$$

ロケットエンジンが定常運転中のとき，次式を満たす．

$$
E p=E t
$$

\section{3 剥離限界ノズル}

サイクル比較の際, ノズル条件は同じにする必要がある. ここでは燃焼室圧力に対応した剥離限界ノズルを用いる. このノズルの膨張比の式を次に示す.

$$
\begin{gathered}
\frac{P a-P s}{P s} \approx 0.55 M s \\
\frac{P s}{P c}=\left(1+\frac{\gamma-1}{2} M s^{2}\right)^{\frac{-\gamma}{\gamma-1}} \\
\frac{A e}{A t}=\left(\frac{2}{\gamma+1}\right)^{\frac{1}{\gamma-1}}\left(\frac{P c}{P s}\right)^{\frac{1}{\gamma}} / \sqrt{\frac{\gamma+1}{\gamma-1}\left[1-\left(\frac{P s}{P c}\right)^{\frac{\gamma-1}{\gamma}}\right]}
\end{gathered}
$$$$
\text { このノズルの推力係数の式を次に示す. }
$$

$C_{F}=\sqrt{\frac{2 \gamma^{2}}{\gamma-1}\left(\frac{2}{\gamma+1}\right)^{\frac{\gamma+1}{\gamma-1}}\left[1-\left(\frac{P e}{P c}\right)^{\frac{\gamma-1}{\gamma}}\right]}+\frac{P e-P a}{P c} \frac{A e}{A t}$

\section{4 推力・比推力}

特性排気速度は, 燃焼室混合比の関数となる。

$$
C^{*}=f(M R c)
$$

推力・比推力の式を次に示す.

$$
\begin{aligned}
& F=\dot{m}_{C} \cdot C^{*} \cdot C_{F} \\
& I s p=\frac{F}{\left(\dot{m}_{C}+\dot{m}_{g}\right) \cdot g_{0}}
\end{aligned}
$$

\section{5. 計算結果}

計算結果を Fig.4 に示す。

\section{1 RS-68}

RS-68 と同じ燃焼室圧力のとき, 計算結果と実際のデー タはほぼ一致した。よって計算手法は妥当であることが確 認された。

\subsection{G.G サイクル}

RS-68に剥離限界膨張比ノズルを採用したとき, 海面上 比推力は RS-68 よりも劣るが, 真空中比推力は向上する. しかし, 燃焼圧が 12[MPa]を超えると, それ以上真空比推 力は上昇しなくなり, さらに $18[\mathrm{MPa}$ を超えると低下する.

\subsection{G.G + EXサイクル}

G.G サイクルに比べて, 比推力は海面上で 2.7〜 4.9 [s], 真空中で 3.4〜5.9 [s]向上する．またできる限り高い燃焼室 圧力にしたほうが，比推力が向上する。しかし燃焼室圧力 が 12.4[MPa]を越えると, サイクル成立解が存在しなくな る.

\section{4 最大 LOX 吐出圧}

Fig.5に G.G+EXサイクルにおける燃焼室圧力によるポン プ吐出压の変化を示す. システムが成立する最大燃焼室圧 力付近において, LOX 吐出圧が急激に上昇する. そのため, それ以上の燃焼室圧力ではサイクルが成立しない.

最大 LOX 吐出圧は 50[MPa]程度となり，これは SSME と同程度である.しかし SSME が一部の LOX を昇圧して いるのに対し，このサイクルでは全ての LOX を昇圧する 必要がある。

\section{5 平均比推力}

飛行高度による比推力の変化を Fig.6 に示す. サイクル 比較のために, 一段目に RS-68 5 基使用する Ares V をリ ファレンスロケットとする. 燃焼室圧力は RS-68 と同じ 9.72[MPa]とし, 高度は Ares Vのデータ(2)より 122[km]まで 計算を行う。この間の平均比推力は, RS-68 が 405.8[s], G.G サイクルが 412.3[s], G.G+EX サイクルが 417.2[s]となる. RS-68 が剥離限界膨張比ノズルを採用するだけで, 平均比 推力が $6.5[\mathrm{~s}]$ 向上するが, EX サイクルとの複合サイクルに すれば，平均比推力がさらに $4.9[\mathrm{~s}]$ 向上する.

\section{6. 結言}

比推力が低い G.G サイクルの比推力を向上させるため, EX サイクルを組み合わせた複合サイクルを考案した.

複合サイクルは，燃焼室圧力に限界があるが，同じ然焼 室圧力において GG サイクルと比較して，比推力を 4.9[s] を向上させることができる. また, ターボポンプのタービ ン駆動ガスとポンプ流体が混合した場合も安全なので, タ 一ボポンプの設計を簡易にし，より信頼性の高いものにで きる。

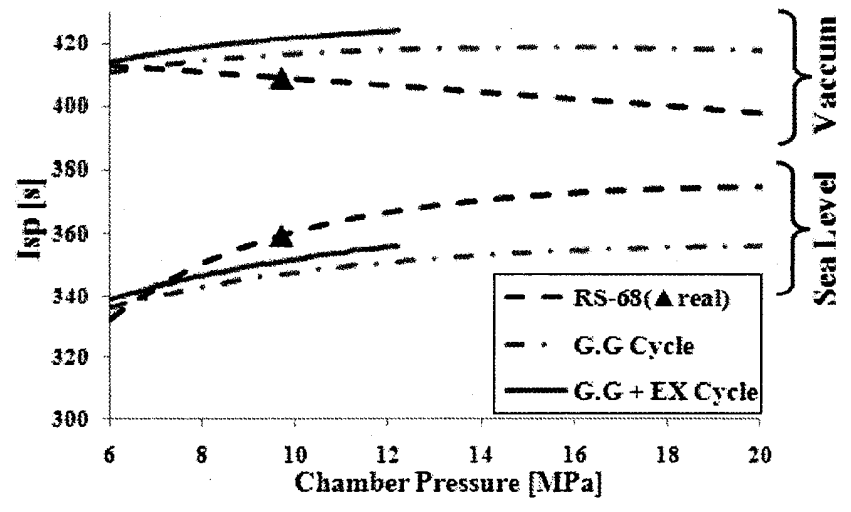

Fig.4 Calculation result

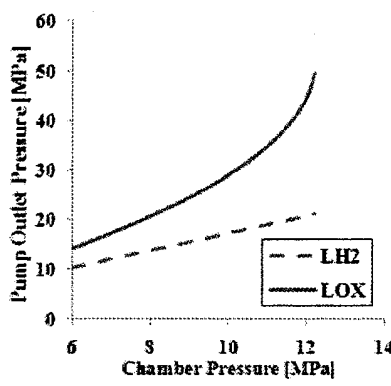

Fig.5 Pump Outlet Pressure 参考文献

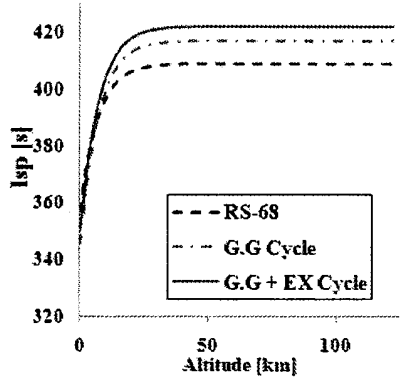

Fig.6 Change of Isp
(1) B. K. Wood 「Propulsion for the 21st Century-RS-68」 AIAA2002-4324, 2002

(2) $\lceil$ Ares V Overview ESMD Technology Exchange Conference $\rfloor$ 